\section{Scientists should unite against threat from religion}

SIR - It was genuinely alarming to encounter Ziauddin Sardar's whitewash of Islam in the pages of your journal ('Beyond the troubled relationship' Nature 448, 131-133; 2007). Here, as elsewhere, Nature's coverage of religion has been unfailingly tactful - to the point of obscurantism.

In his Commentary, Sardar seems to accept, at face value, the claim that Islam constitutes an "intrinsically rational world view". Perhaps there are occasions where public intellectuals must proclaim the teachings of Islam to be perfectly in harmony with scientific naturalism. But let us not do so, just yet, in the world's foremost scientific journal.

Under the basic teachings of Islam, the Koran cannot be challenged or contradicted, being the perfect word of the creator of the Universe. To speak of the compatibility of science and Islam in 2007 is rather like speaking of the compatibility of science and Christianity in the year 1633, just as Galileo was being forced, under threat of death, to recant his understanding of the Earth's motion.

An Editorial announcing the publication of Francis Collins's book, The Language of God ('Building bridges' Nature 442, 110; 2006) represents another instance of high-minded squeamishness in addressing the incompatibility of faith and reason. Nature praises Collins, a devout Christian, for engaging "with people of faith to explore how science - both in its mode of thought and its results - is consistent with their religious beliefs".

But here is Collins on how he, as a scientist, finally became convinced of the divinity of Jesus Christ: "On a beautiful fall day, as I was hiking in the Cascade Mountains... the majesty and beauty of God's creation overwhelmed my resistance. As I rounded a corner and saw a beautiful and unexpected frozen waterfall, hundreds of feet high, I knew the search was over. The next morning, I knelt in the dewy grass as the sun rose and surrendered to Jesus Christ."

What does the "mode of thought" displayed by Collins have in common with science? The Language of God should have sparked gasping outrage from the editors at Nature. Instead, they deemed Collins's efforts "moving" and "laudable", commending him for building a "bridge across the social and intellectual divide that exists between most of US academia and the so-called heartlands."

At a time when Muslim doctors and engineers stand accused of attempting atrocities in the expectation of supernatural reward, when the Catholic Church still preaches the sinfulness of condom use in villages devastated by AIDS, when the president of the United States repeatedly vetoes the most promising medical research for religious reasons, much depends on the scientific community presenting a united front against the forces of unreason.

There are bridges and there are gangplanks, and it is the business of journals such as Nature to know the difference.

Sam Harris

Address withheld by request

www.samharris.org

\section{Religion: Islamic science fading before colonialism}

SIR - In his Commentary on the rise and fall of Islamic science (Nature 448, 131-133; 2007), Ziauddin Sardar's discussion of how modern Muslim societies could be improved by scientific endeavours is encouraging. However, he places most of the blame for the decline of Islamic science on Western colonialism. This is historically inaccurate. Like the tip of an iceberg, colonialism is not the major factor - just the most visible.

It is true that colonialism "displaced meaningful cultural activities from Muslim society," and caused "the general economic and political deterioration of Muslim society" that led to the ultimate collapse of Islamic science. But it's generally accepted that the golden age of Islamic science stretched from about 800-1400 $\mathrm{AD}$, and its decline started more than a century before Western colonialism began in the late fifteenth century.

A number of devastating blows to Muslim society have been implicated in the decline of Islamic science: military invasions, massacres and infrastructure destruction; a long period of drought beginning around $1250 \mathrm{AD}$; and a series of plague epidemics between 1347 and 1515. These destructive developments overlap with the main period of decline of Islamic science in the fourteenth and fifteenth centuries. The onset of European colonialism from the late fifteenth century onward merely completed a process that had begun long before.

Todd P. Silverstein

Department of Chemistry, Willamette University, Salem, Oregon 97302, USA

\section{Berlin shows how natural history can pull the crowds}

SIR - You emphasized the roles that museums should play in both increasing and diffusing knowledge, in your Editorial 'Museums need two cultures' (Nature 446, $583 ; 2007)$. Germany's premier naturalhistory institution, the Berlin museum of natural history, recently demonstrated the potential that museums have to do the latter.

On 13 July, its main palaeontology exhibition reopened after a redesign. The dinosaurs in the main hall are now all mounted according to the latest findings in vertebrate palaeontology. The tallest mounted dinosaur skeleton in the world of Brachiosaurus brancai - is no longer sprawling but striding majestically through the hall. On the opening day, thousands of visitors queued from the underground station, breaking Germany's record for the highest number of visitors to an exhibition during an opening weekend.

The Berlin Brachiosaurus skeleton was first mounted in 1937. Seventy years, although little by dinosaur standards, is a long time for scientists and the public to wait before money is provided for a modern exhibition. Funding bodies must recognize that natural-history museums are in a unique position to explain complex issues in science to a wide audience. But to do so, they need to be able to update their exhibits and present new research to the public on a regular basis.

The results are well worth the investment. During the opening weekend, more than 38,000 visitors preferred the Jurassic period to a day in the Berlin sunshine.

Nizar Ibrahim

School of Biology and Environmental Science, University College Dublin, Belfield,

Dublin 4, Ireland

\section{Puns can be baffling, so keep headlines simple}

SIR - I beg to differ with Renée M. Ned and Lisa N. Steele's Correspondence 'Slang's not so slick when you remember its origins' (Nature 447, 775; 2007) about the use of the word 'pimp' in a News Feature headline ('Pimp my antibody' Nature 446, 964-966; 2007).

The word first appeared in sixteenthcentury France as the verb pimper, meaning 'to dress elegantly', and as the adjective pimpant, 'alluring in dress, seductive'. In the seventeenth century, the word was associated with 'a knave, rascal, varlet, scoundrel', according to the Online Etymology Dictionary (www.etymonline. com). The vulgar modern meaning probably derives from a combination of these. The sense in which it is used by the television show Pimp My Ride could imply dressing an automobile elegantly — admittedly with a hint of flashy style.

I personally find the use of puns, colloquialisms and cultural references more objectionable, as they are likely to be understandable to only a fraction of Nature's global readership. The English language is sufficiently complex without the need to understand these sometimes obscure 
references in the headlines of Nature News stories and other similar articles.

A quick scan of a few issues yields: “...over a pork barrel”; "Oceanography: Churn, churn, churn”; "...science in premier league”; "State of the donation"; "Astrophysics: The answer is blowing in the wind"; "Scot on the rocks"; and "The silence of the robins". As a native English speaker I may understand and appreciate these, but many others wouldn't Jeff Craig

Epigenetics Research Laboratory, The Murdoch Childrens Research Institute, Royal Children's Hospital, Flemington Road, Parkville, Victoria 3052, Australia

\section{Puns: wimp or macho, not a particle of offence is meant}

SIR - Beyond the excellence of the scientific reporting, I particularly enjoy the entertaining use of language and the enlightened levity of Nature. Consequently, I am somewhat concerned by the complaint of R. M. Ned and L. N. Steele ('Slang's not so slick when you remember its origins' Nature 447,775 ; 2007) regarding the use of the verb 'pimp', because of its "immoral origins".

Should I take offence because the use of the terms 'wimp' and 'macho' to denote putative particles might perpetuate negative stereotyping of my gender?

The freedom and, especially, the humour of scientific reporting may be hindered by misguided attempts to avoid offending moralists.

\section{Milan Hopkins}

9479 Main Street, PO Box 638,

Upper Lake, California 95485, USA

\section{Regions unite to challenge inequalities in Brazil}

SIR - The "unequal struggle" of mediumsized university physics departments in Scotland "against larger and moreentrenched rivals" is highlighted by your Editorial 'All for one...' (Nature 447, 1031; 2007). The less developed countries of the world face an even greater problem. How can science help the economic improvement of these countries, taking into account not only "basic challenges in trying to compete globally", but also regional difficulties particularly very limited facilities and insufficient human resources?

As an illustration of the regional problem, take the Human Development Index, which measures quality of life: a score above 0.5 is medium and above 0.8 is high. The south of Brazil scores about 0.84 - not far behind some European countries - whereas the northeast of Brazil is around 0.67.

Along the same lines as the Scottish Universities Physics Alliance described in your Editorial, the Brazilian government and universities created the Northeast Network on Biotechnology, or Renorbio (www. renorbio.org.br) in 2003. Last year a graduate programme in biotechnology was added, consisting of a pool of 29 universities from 10 different Brazilian states.

This initiative is new in the following five ways. It aims to produce $100 \mathrm{PhD}$ graduates a year, which should speed regional development. Many universities that were not strong enough previously to offer a $\mathrm{PhD}$ programme now can, and will also gain research funds. Researchers who join the programme qualify for $\mathrm{PhD}$ students. The universities are becoming more competitive both locally and internationally. They are now expected to produce more patents and publications, creating stronger departments and leading to an increase in the number of knowledge-based enterprises in the region. Luiz A. B. Castro ${ }^{\star}$, Allan Kardec Barros' ${ }^{\star}$ R\&D Policies and Programmes,

Ministry of Science and Technology,

Esplanada dos Ministérios, Bloco E, Brasília, DF, 70067-900, Brazil

$\dagger$ Department of Electrical Engineering, Federal University of Maranhao, Av. dos Portugueses, s/n, Sao Luis, MA, 65080-040, Brazil

\section{Summing up The Simpsons}

SIR — In your amusing News Feature interview with Harvard mathematics graduate $\mathrm{Al}$ Jean, head writer of The Simpsons ('Mmm... Pi' Nature 448, 404; 2007), Jean mentions, as an example of a staggeringly obscure mathematical reference, a number in the thousands that is the sum of four squares. However, as

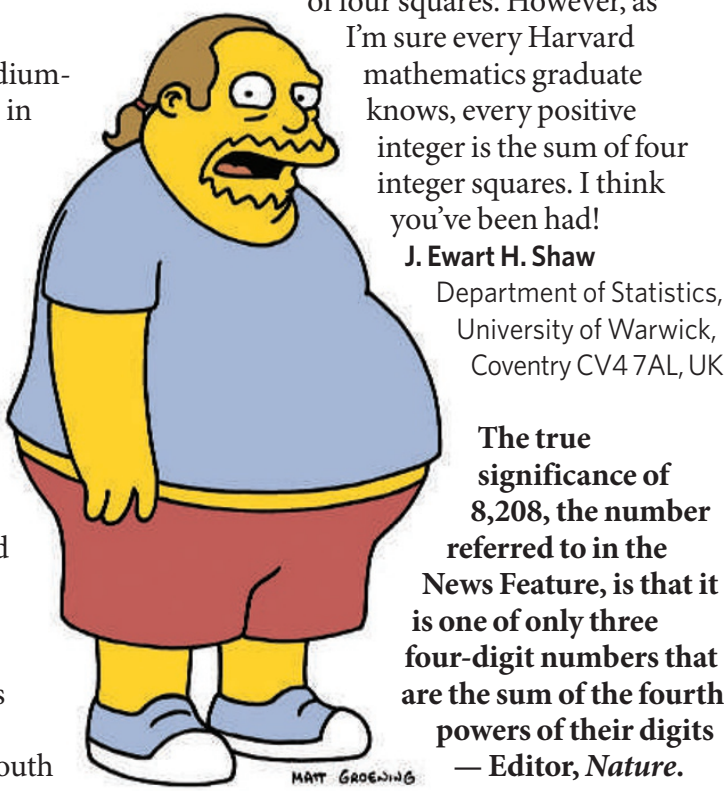

\section{Drop 'higher' and 'lower' to raise descriptive standards}

SIR - For most of the past 2,500 years, the dominant view in the West was that life was graded from better to worse, higher to lower, in a Chain of Being. This could be the product of some creative deity or - as in the eighteenth- and nineteenth-century theories proposed by Denis Diderot, Jean Baptiste de Lamarck and Robert Chambers - a consequence of matter somehow organizing itself through a goal-directed, progressive evolutionary process. Humans invariably occupied the top link.

The scientific literature persists in providing a home for the terminology of the Chain. During the past year, for instance, the Nature.com search facility identifies more than 300 references to 'higher' or 'lower' eukaryotes or organisms.

This usage is misleading, because evolution is not a progressive process. Selection may, in the short term, lead to increases in fitness. But there is no reason to assume that species adapted to the environments they occupy today are better adapted than their precursors were to their environments, and if evolution does not ensure this it hardly qualifies as progressive. Of course, because the first life forms were very simple, it is not surprising that evolution has resulted in increases in specialization or complexity in many lineages. But there is no sense in which such changes can make one taxon higher than another.

An argument in favour of preserving the terminology of the Chain is that it is useful. Yet there is considerable disagreement over the referents of 'higher' and 'lower'. The status of plants, for example, as higher or lower organisms is very fluid. Yeast is typically a 'lower' organism when compared with animals but can be a 'higher' one when compared with bacteria. Perhaps more disturbingly, and in a usage reminiscent of natural theology, non-human mammals can be relegated to the group of lower organisms when they are compared with humans.

A descriptive terminology hardly qualifies as useful if users disagree over what it describes. Moreover, it is rarely the case that using a consistent and scientifically robust terminology is more difficult than using the inconsistent and misleading terminology of the Chain. Distinguishing between plants and animals, for example, or between flowering and non-flowering plants, or between vertebrates and invertebrates, or between humans and other primates/ mammals/animals without resorting to the descriptors 'higher' and 'lower' is easy it's just been done.

Michael Mogie

Centre for Mathematical Biology, Department of Biology and Biochemistry, University of Bath, Bath BA2 7AY, UK 